\title{
O náufrago da rua Toth
}

Ravel Giordano Paz I UEG

Resumo: O trabalho propõe uma leitura do romance mais recente de Chico Buarque, Budapeste, percorrendo seus diversos jogos de espelhos para tentar surpreendê-lo em uma duplicidade mais fundamental: a de um "autor ambidestro", cuja finissima "malandragem escritural", urdida em fios quase invisiveis nas entrelinhas da teia narrativa, configura a potência e os limites do estatuto da práxis e da alteridade em seu interior. Palavras-chave: Literatura Brasileira; Romance contemporâneo; Chico Buarque.

\author{
Sou menino da rua Paulo \\ De um bairro em Budapeste.. \\ (Ira!, "Rua Paulo") \\ Aqui o Narciso é carioca, não morre \\ afogado... \\ (Lobão, "Samba da caixa preta")
}

\section{Dois rios, duas vertigens}

Quem um dia, pescando às margens de um rio e deixando-se absorver por sua correnteza, não conheceu a sensação peculiar de arrastar o mundo num movimento contrário ao que, na verdade, o olhar é conduzido? Não é difícil fazer dessa vertigem mais uma das tantas metáforas para a relação 
dos personagens, narradores ou leitores do romance com sua realidade configurada. Agora suponhamos que se tratem de dois rios, cujas correntes se amalgamassem de tal forma que criassem um fluxo, como diz uma canção de sucesso recente, "sem direção": aí, teríamos uma imagem aplicável ao último romance de Chico Buarque - ou, pelo menos, à poética que ele parece almejar. Pois o fato é que Budapeste é um livro de engenho singular: um livro cujo autor tem algo de ambidestro - algo de um narrador-ilusionista que com uma mão nos enredasse no encanto de sua história e com a outra preparasse, construindo-o em detalhes quase invisíveis, um derradeiro passe de mágica.

Além do mais, metáforas à parte, é preciso reconhecer a maldade que é associar uma obra construída com tanta delicadeza com uma das canções mais bregas das últimas temporadas. Como tantos bons leitores reconheceram, ${ }^{2}$ Budapeste é um romance belíssimo, quem sabe, como escreveu Caetano Veloso, "o mais belo dos três livros da maturidade de Chico". Como ele, também os dois primeiros eram construídos sob os signos da vertigem e da duplicidade, mas o que antes parecia fadado a ser sorvido por um turbilhão implacável - o turbilhão de uma História concebida como acúmulo de catástrofes - agora consegue como que se elevar acima dessas águas turbulentas. Na verdade, as linhas de continuidade de Budapeste com os livros anteriores são até insistentemente sublinhadas. Sobretudo, o olhar algo delirante do narradorprotagonista - chegando mesmo às raias do delírio persecutório (cf. BP, 162) -, com suas idas e vindas um tanto frenéticas e sua osmose com um universo de formas fluídas e espaços permutáveis, aproxima-o bastante de Estorvo. As familiaridades chegam ao extremo de detalhes como a presença de um olho mágico ou agressões similares, como as perseguições por motociclistas, e até idéias e frases retomadas quase integralmente: enquanto o protagonista do primeiro romance anda em seu apartamento "como dentro d'água", o do segundo "escrevia como se andasse em minha casa, porém dentro d'água" (BP, 133). Detalhes que talvez não revelassem mais do que a intenção um pouco ingênua

1. BUARQUe, 2003. Daqui em diante, o romance Budapeste será referido, no corpo do texto, por BP.

2. A orelha da $2^{\underline{a}}$ edição seleciona trechos de comentários de José Miguel Wisnik, José Saramago, Caetano Veloso, Luís Fernando Veríssimo, Beatriz Rezende e Nelson Ascher. As citações sem referência deste trabalho provêm desses extratos. 
de criar uma espécie de "mitologia" própria, se o estranhamento radical não unisse tão profundamente as duas obras: José Costa, pode-se dizer, é um "estorvo" que encontrou um certo lugar no mundo, embora instável e deslocado o suficiente para não privá-lo de sua negatividade essencial. Não tanto, porém, a ponto de tal negatividade não poder se transmutar em seu contrário, de modo que àquela frase se segue esta: "Era como se meu texto em prosa tomasse forma de poesia" (BP, 133). De fato, não é apenas "quando termina”, como escreveu José Miguel Wisnik, que Budapeste "transforma-se em poesia", embora essa última transformação seja não só definitiva como muito mais ampla, pois envolve a totalidade da diegese narrativa. Mas essa não desprezível vitória do espírito sobre o mundo paga um preço, qual seja, o de que aquelas águas terminem, se não totalmente estagnadas (para usar uma expressão do próprio narrador), no mínimo domesticadas no interior do mesmo universo simulacrizado - tornado benéfico por obra de um sutil gesto ilusionista, ou uma finíssima malandragem escritural - em que elas irrompiam ferozmente nos livros anteriores.

Dizer "o mesmo universo" talvez seja excessivo; afinal, não se pode igualar o simulacro da escritura, índice de liberdade, às simulacrizações repressoras do mundo contemporâneo: de modo algum a potência transfiguradora daquele é redutível à propensão anuladora das últimas. Além disso, não é sem uma não menos fina auto-ironia que aquela "malandragem" se configura. Ainda assim, os deslizamentos de sentido e de potência pragmática existem: as duas formas de simulacro se tocam e se imiscuem, e pelo menos dessa vertigem é só às custas de um auto-ilusionismo que o malandro-narciso pode escapar.

Mas vamos por partes - ainda que isso signifique a improvável tarefa de, parafraseando o narrador de Budapeste, cortar um rio (ou dois) a faca...

\section{Uma sombra em ascensão}

Muito antes de se ver dividido entre dois nomes, duas línguas, duas cidades e duas mulheres, José Costa é um indivíduo cindido em sua própria práxis, o que se projeta numa dimensão existencial profunda; assim, quando essa cisão atingir seu estatuto de narrador, não estará mais do que levando ao extremo tal condição. Ghost-writer profissional, Costa é alguém "destinado à sombra", na medida em que vende, além do fruto, a autoria de seus trabalhos. Mas nem por isso deixa de se regozijar quando estes passam a ser publicados sob a rubrica de "nomes mais e mais ilustres", o que para ele equivaleria a 
"progredir de sombra" (BP, 16). Mais do que isso, o anonimato é uma forma oblíqua de celebridade, permitindo-lhe desfrutá-la sem se submeter a ela. Desse modo, o que parecia uma condição de inferioridade torna-se uma irônica forma de poder.

Anoitecia, e eu tornava a ler os fraseados que sabia de cor, depois repetia em voz alta o nome do tal sujeito, e balançava as pernas e ria à beça no sofá, eu me sentia tendo um caso com mulher alheia. E se me envaideciam os fraseados, bem maior era a vaidade de ser um criador discreto. (BP, 18)

A questão do estatuto e dos limites da práxis humana em um mundo marcado por relações despersonalizadas, onde o espetáculo e o anonimato compõem as duas faces visíveis de uma lógica mais profunda - a do capital, é claro -, é uma problemática central em Estorvo e Benjamim, e, mais do que sua persistência, a centralidade que ela assume em Budapeste é um dos índices de que as linhas de continuidade entre os três romances estão longe de ser circunstanciais. Se no primeiro deles essa problemática tomava a forma de uma anulação quase absoluta da práxis consciente do narradorprotagonista em sua relação com o mundo - apenas em um nível inconsciente, quase puramente patológico, seus gestos e atos podendo recusá-lo -, enquanto no segundo se abria a possibilidade - mas ainda semiconsciente para seu protagonista, cuja "consciência oculta" se desdobrava em uma espécie de "câmera dialógica" - dessa práxis dar novas direções, ainda que oníricas e fadadas ao fracasso, à mesma realidade espetacularizada que a tolhia, ${ }^{3}$ no terceiro essa possibilidade se torna mais concreta do que nunca, a ponto de José Costa fazer dela uma possibilidade de realização existencial.

Mas é claro que isso não pode se configurar senão sob o signo da precariedade. Afinal, não há apenas confluência, mas também conflito entre lirismo e prosaísmo em Budapeste: se, numa imagem entre lírica, grotesca e humorística, ${ }^{4}$ os pães de abóbora húngaros se fundem a um, digamos, farináceo

3. Explorei essas questões em minha dissertação de mestrado, Estações\#encru-zilhadas: o inferno e o sonho, a música e o mundo nos romances de Chico Buarque.

4. Já em relação a Estorvo Marcelo Coelho apontava a presença recorrente da catacrese, vendo nela a representação de um universo social delirante (cf. COELHO, 1991). Em Budapeste se torna mais clara do que nunca a dimensão lírica desse recurso, que afinal conduz a uma espécie de lirismo truncado. 
tupiniquim - "o Pão de Açúcar iluminado ao fundo, cor de abóbora" (BP, 36) -, a adaptação de Costa/Kósta à realidade e ao idioma estrangeiros será progressiva e tortuosa. A própria cisão encontra-se espelhada na capital húngara, dividida, por um Danúbio de águas ora escuras ora amarelas, em Buda e Pest - e não custa lembrar que já em sua referência literária talvez ainda hoje mais famosa, o tão ingênuo quanto doloroso Os meninos da rua Paulo, de Ferenc Molnár, essa mesma cidade surgia marcada pela cisão territorial, e até por um certo sentimento de desterro , enquanto o idioma magiar é atravessado por dialetos e outras línguas. Finalmente, a mesma articulação entre elementos como espetáculo, apartamento, barbárie e anulação dos primeiros romances de Chico Buarque não é menos atroz em Budapeste, onde ela também encontra no fluxo das imagens midiáticas sua manifestação mais explícita. No início do segundo capítulo, José Costa assiste à esposa anunciando, em um telejornal, uma "reviravolta no caso das crianças dos olhos furados" (BP, 13). E ainda que tematicamente menos explorada, ou mesmo um tanto diluída no tom lírico da narrativa, o fato é que pelo menos em seus reflexos existenciais essa articulação tornou-se aqui ainda mais onipresente, a ponto de mesmo a única "transcendência" entrevista pelo narrador-protagonista de Estorvo - a derradeira anulação em um horizonte umbroso - revelar-se radicalmente tolhida pela redução de tudo a um voyeurismo ostensivo, característico da sociedade de espetáculo:

Tinha mais meia hora de marcha sob um céu carregado, e às vezes me debruçava no parapeito da ponte para olhar o Danúbio, negro, silencioso. Levava um bom tempo para me convencer de que ele se movia, e um ou outro carro sempre parava por perto, na aguarda, para ver se eu me atirava ou não. (BP, 70)

E, como vimos, mesmo a inversão que o culto ao anonimato de José Costa estabelece em relação à lógica do espetáculo é extremamente relativa: o prazer da fuga aos refletores é proporcional ao tamanho da "sombra" em que esse ocultamento o transforma.

O paradoxo de que seja sob tal onipresença que se dê aquela derradeira "vitória" do espírito sobre o mundo é aparente: é justamente tal condição que exige, como única solução "positiva" convincente, uma

5. MOLNÁR, [s.d.]. 
transfiguração lírica que englobe a totalidade da diegese narrativa. E é justamente por guardar um certo parentesco com as exigências do mundo do espetáculo que o culto ao anonimato do protagonista está fadado, em sua necessidade de autosatisfação, a se desdobrar infinitamente, num moto-contínuo cujo término só pode ser, naturalmente, um tipo de auto-devoramento, o que nesse caso equivale a uma solução metalingüística - outro nome para aquela transfiguração totalizadora. Mas como se dá esse movimento, e em que sentido, afinal, ele se funda em um gesto dúplice - não apenas encantatório, mas também ilusionista?

\section{Espelhos caudalosos}

Antes de mais nada, é preciso reconhecer, sob a ambigüidade disseminada em todas as suas instâncias, a unidade das motivações profundas de Budapeste. O principal motor da narrativa, das vertiginosas idas e vindas de José Costa, ou Zsoze Kósta, entre o Rio e Budapeste, entre os braços (mas também a rejeição) de Vanda e de Kriska, entre o frenesi da sintaxe em português e o primor das construções em húngaro, consiste na tentativa de se criar um espelho ao mesmo tempo fiel e transfigurador da condição existencial do narrador - digamos, de sua condição existencial "originária" - e do mundo em que ela se gerou. Essa afirmação pode parecer um tanto chocante, em se referindo a uma obra tão marcada pelo cosmopolitismo e pela liberdade no jogo com os elementos simbólicos de seu duplo eixo espacial. O fato, porém e isso por mais que Chico Buarque zele por aquela liberdade -, é que ainda aqui valem as palavras com que José Cardoso Pires saudou a publicação do primeiro romance de Chico Buarque, vendo nele "uma busca de identidade o trabalho de alguém que, através das personagens e da escrita, procura uma identificação consigo próprio, com a realidade vivida e com a língua em que se exprime." Em resumo, é preciso acentuar esse dado nem sempre óbvio: as vivências relativas ao Rio de Janeiro e a Budapeste não têm o mesmo estatuto para Costa/Kósta, e é às primeiras que cabe a primazia, embora de forma alguma a exclusividade, enquanto doadoras de densidade existencial para o personagem.

6. PIRES, 1991, p. 01. 
É em resposta à experiência entranhada e incessantemente reiterada de uma espécie de deriva lingüística e existencial - e aqui linguagem e existência praticamente se equivalem -, vivenciada na comunicação emperrada com o sócio, a mulher e o filho, ou nos retalhos de diálogos apreendidos em Ipanema - mas também entrevista no silenciamento ostensivo em relação à infância; é em relação a tudo isso que a língua húngara, Kriska e Budapeste surgem como um primeiro e dúplice espelho para Costa: um espelho que, antes de mais nada, amplia as mal ajustadas peças de sua existência. Assim, em meio a sua exclusão do universo lingüístico-existencial do filho - que "falava mamãe, babá, pipi”, mas em nenhum momento "papai" (BP, 31) -, é somente pela intermediação de um elemento ainda "sem nexo" (idem) - ou seja, justamente o húngaro - que Costa se reconhece nele.

Como vimos, porém, a relação do narrador-protagonista com a linguagem comporta outras dimensões: a de uma possibilidade de realização existencial conjugada a um certo exercício de poder. Por mais marcadamente poética que a prosa de Chico Buarque se torne no episódio dedicado à composição da "autobiografia" do empresário alemão Kaspar Krabbe por Costa, este é um dos momentos mais marcados por essa conjunção. Algo que não se realiza propriamente na vaidade desmesurada que escrever o best-seller "O Ginógrafo" proporciona a seu verdadeiro autor, que não pode evitar chamá-lo de "meu livro" (BP, 93). Pelo contrário: ao concluir o romance a condição de "sombra" já não satisfaz José Costa, e à consciência da necessidade de entregálo ao "biografado" se alia um sentimento de impotência: "Eu via minhas palavras soltas na tela e, horrorizado, imaginava que elas me abandonavam como o alemão perdia pêlos" (BP, 41). Sentimento que, consumada essa entrega, tornase uma verdadeira deriva existencial: "Depois de um tempo fitando a arrebentação das ondas e a linha da água a progredir na areia, senti o corpo descair de leve para a frente; era como se em vez de subir a maré, o continente adernasse" (BP, 41). Isso, talvez, porque fora num plano mais profundo, envolvendo a totalidade de sua condição existencial, que aquela possibilidade se revelara para Costa: na experiência, através da reinvenção da vida de uma alteridade - uma experiência "imaginária" mas ainda assim literal -, de reterritorialização da linguagem no corpo de outras alteridades. Experiência, no entanto, que é também, de um certo modo, de apropriação utilitária desses corpos pela própria linguagem: o lirismo febril da passagem em que Costa/ Krabbe relata a criação de seu livro em coxas, pernas, nádegas, braços e pescoços 
femininos não suprime o fetichismo desse ato. O que por sua vez não impede que ele se alie a um sentimento de plenitude, num encontro derradeiro em que à criação literária se conjugará a criação de uma nova existência e, finalmente, uma espécie de recriação existencial, de conquista de uma "nova infância", para o próprio "ginógrafo":

Foi quando apareceu aquela que se deitou em minha cama e me ensinou a escrever de trás para diante. Zelosa dos meus escritos, só ela os sabia ler, mirando-se no espelho, e de noite apagava o que de dia foi escrito, para que eu jamais cessasse de escrever meu livro nela. E engravidou de mim, e na sua barriga o livro foi ganhando novas formas, (...), até que eu cunhasse, no limite das forças, a frase final: e a mulher amada, cujo leite eu já sorvera, me fez beber da água com que havia lavado sua blusa. (BP, 40)

Já aqui se entrevê a possibilidade de, pela primeira vez, o mesmo movimento de "eterno retorno" presente nos livros anteriores se configurar de forma positiva. Não obstante, tanto o sentimento de posse participa dessa articulação entre corpo e linguagem, tão cara à filosofia contemporânea, que é justamente quando se vê ameaçado não só no segundo mas também no primeiro desses territórios - ou seja, em relação à posse do corpo da esposa, peremptoriamente referida como "minha mulher" -, que José Costa viola seu código profissional e revela: "o autor do livro sou eu" (BP, 111-112).

É, portanto, essa dupla ou tríplice condição que as experiências relativas a Budapeste refletirão, ou melhor, a ela tais experiências se articularão, dando-lhes novas dimensões. Assim, o húngaro significará, para o narradorprotagonista, tanto a ampliação da incomunicabilidade vivenciada em sua língua nativa quanto da satisfação de dominar, progressiva e cada vez mais perfeitamente - um processo, no entanto, que só se completará de forma paradoxal -, um novo território lingüístico. São vários os episódios que concentram esse duplo movimento. Por exemplo, quando Costa começa a se dirigir em húngaro aos moradores de Budapeste, e se depara sempre com um mesmo "olhar mortiço"; o que não o impede de sublinhar: "No entanto, a cada dia eu mais me orgulhava de meus conhecimentos, pouco importava que todos os húngaros me olhassem com aquele olho de peixe" (BP, 66). Assim, habilitarse "a retocar por conta própria o húngaro dos maiores escritores da Hungria" (BP, 126), e em seguida tornar-se o ghost-writer de um deles, significará a suprema realização para Zsoze Kósta. Ao mesmo tempo, esse preciosismo cada 
vez maior na relação com a nova língua trará a possibilidade de um contraponto ao contexto de vulgarização da língua portuguesa - tão marcado no episódio dos fragmentos de diálogos em Ipanema (BP, 14) -, e, num certo sentido, até mesmo de seu resgate desse contexto; algo que em última instância se reflete na dimensão estilística do romance, conduzindo a uma prosa - certamente é esse o "algo novo" a que se referiu José Saramago - ao mesmo tempo fluída e depurada. Afinal, é preciso adentrar e se banhar com cuidado nesse rio - nessa língua, como imagina o narrador ao ouvi-la pela primeira vez, "sem emendas, não constituída por palavras, mas que se desse a conhecer só por inteiro" (BP, 08).

À mesma idéia de uma totalidade indivisível e, a rigor, inabarcável, liga-se o corpo de Kriska, quando Costa, "desnorteado com tamanha brancura", o contempla pela primeira vez: "Por um momento imaginei que ela não fosse uma mulher para se tocar aqui ou ali, mas que me desafiasse a tocar de uma vez só a pele inteira" (BP, 46). Enfim, é numa transposição da articulação entre linguagem e corpo para um contexto associado a uma vastidão simbólica e marcado por um estranhamento singular que reside a possibilidade de resgate existencial para o narrador-protagonista. Algo nada simples, afinal essa transposição é menos uma "aclimatação" ou "refundação" num território seguro do que o mergulho em um duplo espelho vivo, do qual não será tão fácil reemergir.

\section{Um náufrago na rua Toth(er)}

Em uma narrativa inquietante, intitulada "A família Tóth", o escritor húngaro István Örkény conta a história de um oficial hospedado pela família de um soldado e que, após uma sucessão de fatos algo absurdos, termina trucidado por seus anfitriões. ${ }^{7}$ Por mais circunstancial e incompleto que seja, não deixa de ser curioso o paralelo entre os destinos do major Varró e do ghost-writer brasileiro que, recolhido à rua Toth nº 84, também passará por uma espécie de imolação, felizmente menos drástica. Paralelo que se amplia 
refletido em um espelho ainda mais fortuito - mas mesmo o crítico não pode se reservar uma margem mínima de liberdade? -, e além disso "alienígena" para os dois personagens: a língua inglesa, onde o nome próprio Toth, ou Tóth, lembra o pronome informal tother, contração da expressão "the other".

De qualquer forma, encimadas ou não pelo emblema da alteridade, ambas as casas são, de fato, lugares de experiências-limite para ou com um outro nelas acolhido. Algo que se configura de forma mais complexa no romance de Chico, em parte pela própria complexidade da diegese romanesca mas sobretudo porque, como vimos, desde o início a experiência da alteridade é fulcral para esse próprio outro - ou seja, para seu narrador-protagonista -, principalmente no que diz respeito à possibilidade de subsumi-la de alguma forma em si mesmo.

Já a primeira aventura de Costa pelas ruas de Budapeste consiste numa inversão grotesca dessa possibilidade. O encontro com um casal de jovens, inicialmente tidos como húngaros mas afinal identificados, corretamente ou não, como ciganos romenos, defronta-o não só com destinos marcados por uma deriva existencial - e, portanto, uma irredutibilidade a qualquer subsunção identitária - ainda mais radical que a sua, como com a possibilidade de submersão definitiva na morte. No último lance da roleta-russa iniciada pelos jovens, Costa lhes impõe respeito ao levar o cano do revólver à boca: acreditando que ele estivesse vazio, sente-se "numa condição de artista"; mas ao engatilhálo, essa articulação entre simulação e poder se desvanece: "Senti no paladar que a arma tinha chumbo, ela já desprendia chumbo na minha boca, e agora era tarde, eu não podia me deter. Só me restava premer o gatilho aos poucos, na esperança de que a bala saísse devagar (...)." (BP, 55)

Mas será na "segunda saída" desse Quixote sem ideais nem Dulcinéia que se dará o encontro com a alteridade que se investirá de sentidos mais amplos e terá ressonâncias mais profundas em sua nova existência, e que não é outra senão Kriska, a moradora da Tóth utca, 17,84,Újpest. Como vimos,

8. Para Costa, na verdade, marginal, pois ele indica em vários momentos dominar o inglês. O fato, porém, é que, como demonstrou Arthur Ferraz, quase todos os nomes próprios húngaros de Budapeste, incluindo os de ruas, praças, etc., são uma homenagem à seleção húngara da Copa de 54, vice-campeã e responsável pela desclassificação da brasileira. Toth era o ponta direita da seleção, nas palavras de Ferraz, "até hoje considerada uma das maiores equipes de todos os tempos" (FERRAZ, 2004). 
um primeiro sentido a que Kriska - ou, antes, seu corpo - se vincula é o de uma totalidade inabarcável e indivisível. Um sentido de plenitude que também se exprime na possibilidade, a que também se liga a personagem, de reinstauração de uma comunicabilidade plena, ou mesmo "mágica", como que anterior à própria linguagem:

E quando ela me afirmou que a língua magiar não se aprende nos livros, fiquei pasmo, porque a sentença me soou perfeitamente inteligível. (...) Talvez a moça tivesse um modo de cantar a língua que, mesmo sem compreender, eu pegasse de ouvido. Talvez apenas pela entonação, eu entendesse o que ela queria dizer. Ou talvez por entender a música, adivinhar a letra me parecesse fácil. (BP, 59-60)

Logo adiante, no entanto, algo de mais profundo se somará a essa "musicalidade":

Segui observando seu silêncio, decerto mais profundo que o meu, e de algum modo mais silencioso. E assim permanecemos outra meia hora, ela dentro de si e eu imerso no silêncio dela, tentando ler seus pensamentos depressa, antes que virassem palavras húngaras. (BP, 61)

O silêncio insondável de Kriska, que parece gestar o destino de Costa - é logo em seguida que ela lhe entrega um cartão com seu endereço, daí a pouco tornado o único pensamento do protagonista -, contém, e pode emprestar-lhe por alguns momentos, aquilo que o culto ao anonimato deste apenas simula, ou seja, uma liberdade e uma integridade alheias às exigências do mundo:" "Acho que me apeguei àquele silêncio, e a fim de prolongá-lo me recolhi ao quarto, onde passei o resto da noite olhando para o teto" (BP, 62).

9. Mesmo quando parece se ligar de alguma forma às idéias de espetáculo ou simulação, é com objetivos "pedagógicos" em relação a Costa que Kriska o faz (cf. BP, 64 e 115-116). Cf., por outro lado, a fuga dos refletores da personagem no lançamento do livro de Kocsis Ferenc "falsificado" pelo protagonista (BP, 141). Quanto à filmagem do retorno deste à Hungria, levada a cabo por Kriska, sem dúvida se relaciona à ambígua consagração do reino do simulacro ao final do romance, e é marcada por tal estranhamento que quando Costa busca os olhos da namorada não os encontra, pois "seu olho esquerdo estava fechado, o direito escondido atrás da filmadora..." (BP, 168). Significativamente, no entanto, esse estranhamento também se liga à gravidez de Kriska, um dos instrumentos da "reabilitação" de Costa. 
Ainda como o protagonista do primeiro romance, também o deste - no fim das contas, quase tão inapto para a vida adulta quanto o outro - se revela cindido por pulsões contrárias de expansão e recolhimento, e é sobretudo em Kriska que ele busca abrigo para o segundo desses impulsos, de modo que há uma oscilação - por vezes uma dialética - entre a configuração da personagem como uma alteridade efetiva e como uma alegoria desse espaço de acolhimento.

Mas o que habita os abismos de Kriska? Quem sabe "uma palavra arcaica, derivada da voz de alguma ave noturna, uma palavra caída em desuso de tão atroz", uma palavra capaz de fazer um Zsoze Kósta já íntimo não só de seu corpo mas também de seu idioma - e prestes a abandoná-los - "andar torto de arrependimento pelo resto da vida” (BP, 151). Não é de se estranhar que seja pelas mãos de Kriska que aquela articulação entre corpo, linguagem e poder, inscrita na práxis e na condição existencial do protagonista, passe pelas provações mais duras; provações que se tornam uma verdadeira imolação quando, após o frustrado retorno ao Rio, ele for recolhido, quase à beira da morte, em frente à "vila de casas gêmeas" da rua Toth. Exibindo o espetáculo de sua miséria aos homens que levava para casa, e depois recolhida ao quarto, sem ter sequer "a delicadeza de fechar a porta", Kriska não só humilha Costa em sua individualidade e masculinidade como ainda o reduz a uma estado de "expressão" pré-lingüística, também neste caso próximo à animalidade, mas agora sem nada de sublime: tentando abafar os sons vindos do quarto da exnamorada, o protagonista ouve as gravações do Clube das Belas-Letras, que fora encarregado de transcrever, no volume máximo; no momento de trocar as fitas, porém,

era obrigado a emitir uns sons incidentais, fazia nham nham nham, nhom, nhom, nhom, e mesmo assim às vezes ouvia gemidos no quarto. E se me excedesse nesses meus sons, eles no quarto caíam às gargalhadas; Kriska até hoje pensa que nham nham nhom nhom é a língua falada na América do Sul. (BP, 116)

Também a Benjamim este terceiro romance de Chico Buarque se liga por alguns traços muito peculiares. O mais evidente deles são as imagens que parecem remeter à tragédia clássica, sendo que uma delas, a mais "clássica" de todas, chega a se tornar recorrente: enquanto Benjamim ouvia das ex-namoradas frases como "por você eu furo meus olhos", na primeira despedida de Costa Kriska vira o rosto, "e no relance pareceu que em lugar dos olhos tinha duas 
postas de sangue" (BP, 73); na segunda, é ele quem aguarda que ela lhe arranque os olhos das órbitas (BP, 151) - sem nos esquecermos, enfim, do "caso das crianças dos olhos furados". E como antes, também aqui tal recurso, à primeira vista superficial, aponta na verdade para a presença de uma estrutura trágica, embora de uma tragicidade cristianizada, pois orientada para fins redentores.

Não é difícil perceber em que consiste a hybris de José Costa: em querer abarcar o inabarcável, constitua ele a linguagem ou a totalidade existencial das alteridades com que se depara. Em termos mais prosaicos, isso se reflete em práticas bastante significativas, como as relações quase brutais com as pessoas mais humildes, sobretudo as empregadas (cf. BP, 78): a mesma herança autoritária que asfixiava o "estorvo" do primeiro romance se ajusta um pouco melhor ao escritor-fantasma deste segundo - ainda que acabe por tomar a forma de um terno enxovalhado. No entanto, a imolação a que Kriska submete o personagem é apenas o início do seu processo de "purificação". Esta só se completará por meio de algo mais que parece residir nas profundezas de sua namorada, ou pelo menos em seu passado, que Costa/Kósta tenta, em vão, ignorar; algo que pode ser literalmente designado como uma outra alteridade, e que não é ninguém menos que o ex-marido da personagem: "Esse ex-marido com quem ela só se comunicava por intermédio do filho, que um depositava para o outro sacar na escola, esse homem eu poderia desconsiderar, como uma alucinação de Kriska." (BP, 69) Uma alteridade tão radical e de nome tão obscuro quanto aquela "palavra estupenda", mas que ao contrário dela não deixará de vir à tona, na forma de um certo Sr...., personagem que não é outro senão o responsável tanto pela "usurpação" da palavra do narrador-protagonista quanto por seu "resgate" final; ou seja, por sua anulação e sua consagração definitivas.

\section{Duas derivas}

É como um misterioso membro do Clube das Belas-Letras - onde, segundo Costa, "exercia grande influência, mesmo sendo homem de poucas palavras, sem obra publicada, que eu então soubesse" (BP, 135) - que surge o "esquivo Sr....". Qual a surpresa do protagonista ao se deparar, em um dos encontros anuais de escritores anônimos, no qual fora parar por um estranhíssimo acaso, com o personagem anunciando-se como o verdadeiro autor de obras de prosadores consagrados em seu país. A surpresa não é tanta, porém, que o impeça de desbancá-lo, declarando-se o autor dos poemas húngaros mais 
celebrados dos últimos tempos. Novamente a linguagem surge associada a um exercício de poder, intensificado por se dar em território alheio:

Preferi humilhá-lo com a poesia, arte que ele ignorava, e que o faria sofrer muito mais por não saber onde lhe doía. Eu declamava os versos lentamente, havia palavras que eu quase soletrava, pelo prazer de vê-lo se remexer na cadeira. Eu fazia longas pausas, silêncios que só um poeta se permite, e ele baixava o rosto, olhava para o lado, para seus montes de livros, chegou a juntar os livros no colo, fez menção de se retirar. (BP, 145)

Ato que sofrerá um revés, pelas mãos do próprio Sr...., com a expulsão de Costa da Hungria. De volta ao Rio, o protagonista se verá em um ambiente brumoso, uma espécie de limbo habitado por "dublês" e "figurantes" de um filme:

Acho que eu tinha conservado da cidade uma lembrança fotográfica e agora tudo o que movia em cima dela me dava a impressão de um artifício. Enfim eu me sentava num banco à beira-mar e ficava espiando os barcos; mesmo o oceano, na minha memória, estivera a ponto de se estagnar. (BP, 154)

Ele próprio ganhará um ar fantasmagórico o bastante para ser abordado por transeuntes que parecem tomá-lo "por outro". Uma alienação, um tornar-se outro radical - que naturalmente não exclui o tema (sérgio)buarqueano do estrangeiro em sua própria terra - acirrado pelo afastamento definitivo em relação ao sócio, o filho e a mulher. O primeiro, que já o denominara "gênio", sequer atende seus telefonemas, e o segundo será justamente um dos "jovens musculosos, de cabeças raspadas e abundantes tatuagens" que o perseguirão em uma moto, por muito pouco não o espancando: assim, sob a superfície do "mar sereno" que compõe como que a trilha sonora daquele filme em câmara lenta, algo mais turbulento ameaça irromper e tragar o protagonista. Quanto à ex-mulher, Costa vê seu apartamento iluminado pela brasa do cigarro de "alguém" não identificado, numa repetição do gesto com que ele outrora tentara, ali mesmo, "demarcar território" (BP, 78); e quando vê entrar no edifício um carro que acredita ser o dela, depara-se apenas consigo mesmo no "espelho" dos vidros negros, "as olheiras, a barba por fazer, o terno todo amarrotado" (BP, 163). Ainda aqui a linguagem, novamente associada à música, surge como uma mediação mais rica: 
O que me prendia a atenção era mesmo uma nova sonoridade, havia um metabolismo na língua falada que talvez apenas ouvidos desacostumados percebessem. Como uma música diferente que um viajante, depois de prolongada ausência, ao subitamente abrir a porta de um quarto pudesse perceber. (BP, 155)

Não deixa de ser curiosa, e sem dúvida significativa, a forma positiva que essa imagem de conotações bastante conhecidas - a de surpreender algo ao se abrir a porta do próprio quarto - assume nessa associação; um passo no qual a experiência lingüística deixa de ser um instrumento de poder para se aproximar de uma forma de abdicação do mesmo, e que talvez já prepare o último lance do romance. Um outro "metabolismo", porém, ainda assinala a deriva de Costa: a "transformação" do best-seller "O Ginógrafo" em "O Naufrágio".

É em meio a essa deriva aparentemente definitiva que a sorte do personagem sofre um novo revés. Após um convite do cônsul da Hungria para retornar ao país com visto permanente, Costa, novamente Kósta, se descobre o aclamado "autor" de um livro que não escrevera: seu romance autobiográfico, intitulado Budapest, "falsificado" pelo Sr..., que só então se revela como o exmarido e pai do filho de Kriska, a qual por sua vez reaparece grávida.

Trata-se, naturalmente, de uma consagração ambígua, em que se completa o processo de inversão das relações de poder configuradas na práxis do protagonista, efetivando-se pelas mãos de uma alteridade incômoda por habitar o passado de uma mulher amada - "e não me entrava na cabeça que ela tivesse um dia se deitado com aquele sujeito" (BP, 168) - e, mais ainda, que lhe subtrai a individualidade, tornando seus gestos, palavras e pensamentos não só estranhos a si mesmo como, literalmente, de domínio público:

Populares me paravam na rua, me solicitavam o autógrafo em seus exemplares, e com mão dormente eu escrevia dedicatórias que me eram estranhas. (...) Em palestras, ainda tentava falar de improviso, tinha um ou outro lampejo de espírito, mas meus leitores já os conheciam todos. Eu ideava palavras estrambóticas, frases de trás para diante, um puta que pariu sem mais nem menos, mas nem bem abria a boca, e na platéia algum exibicionista se me antecipava. (BP, 171)

Consagração também, portanto, daquele limbo de simulacros, cujo domínio invade até os sonhos, único momento em que Zsoze Kósta, vendo-se "numa ponte do Danúbio, às horas mortas, a fitar suas águas de chumbo", volta a 
desfrutar uma certa "onipotência": a de acreditar-se capaz de dar à sua história "um desfecho que ninguém previra"; ainda aí, no entanto, "o sol nascia, se esverdeavam as águas, daí a pouco me via de novo com os movimentos restritos", e sujeitos ansiosos por "aparecer no livro" o puxavam de todo lado, fazendo-o acordar "enroscado no lençol, aliviado por me encontrar ao lado de Kriska, que pelo menos estava no livro desde o início" (BP, 171-172).

Enfim, agora é no próprio universo da simulação que a existência de Costa se vê prestes a submergir. Algo talvez inevitável, não fosse o paradoxo de que o mergulho pleno nesse universo tenha se tornado a única possibilidade de transcendê-lo, o que naturalmente só é possível graças à sua identificação com o universo da escritura. Assim, quando Kriska pedir a Kósta/Costa que lhe leia sua falsa mas fiel autobiografia, será preciso que ele aprenda "a tomar distância do eu do livro" para que a leitura comece a fluir, mas também para que se convença "de ser o verdadeiro autor do livro", e, afinal, para que os planos da diegese narrativa, ou suas correntes contrárias, misturem-se definitivamente:

...agora eu lia o livro ao mesmo tempo que o livro acontecia. Querida Kriska, perguntei, sabes que somente por ti concebi o livro que ora se encerra? Não sei o que ela pensou, porque fechou os olhos, mas com a cabeça fez que sim. E a mulher amada, de quem eu já sorvera o leite, me deu de beber a água com que havia lavado sua blusa. (BP, 174)

A forma como se consuma a "purgação" do personagem é, sem dúvida, um movimento de notável beleza. Levando ao extremo uma possibilidade reivindicada pela criação literária, Chico Buarque inverte a noção lingüística do pronome dêitico como marca constitutiva do sujeito: não é quando diz "eu sou", e sim na enunciação realizada por um outro, que se "reconstitui" a identidade de Costa/Kósta. Há nesse paradoxo algo de uma utopia existencial, uma utopia que inverte um processo de afirmação identitária ligado a práticas sutilmente autoritárias e marcadamente competitivas - configuradas, aqui, sob a forma de uma "malandragem" um tanto narcísica à qual repugna qualquer derrota em suas disputas com Deus e os homens. ${ }^{10}$ No final de Budapeste, mesmo quando volta a se apossar aos poucos de seu discurso, o narrador-

10. Canções que ilustram tais aspectos da "malandragem" em Chico Buarque - questão que também abordei em meu mestrado - são "Aquela mulher" e "Sobre todas as coisas", aqui a disputa amorosa entre o eu lírico e Deus configurando algo como uma "metafísica da malandragem". 
protagonista deve aprender a aceitar sua derrota como a única possibilidade de vitória - "E por mais que padecesse aquela criatura [Costa/Kósta], Kriska tampouco demonstrava grande comiseração. Pois se tinha pelo eu do livro alguma simpatia, era com seu desumano criador [Sr....] que ela se encantava (BP, 173)" -, e, afinal, a não mais estigmatizar, e sim incorporar o mistério da alteridade, novamente vislumbrado nos olhos fechados de Kriska, à plenitude do contato.

É evidente, porém, que esse gesto não pode abarcar a totalidade dos conflitos configurados no romance. A diversidade das práticas a que se liga essa "malandragem" redimida não pode ser subsumida na verticalidade da relação entre Costa, Kriska e o Sr.... Não pode ou não poderia, pois é no gesto capaz de produzir tal artifício que Budapeste se revela em toda a sua ambigüidade. Gesto e artifício que consistem em fazer do terceiro desses personagens - ou melhor, da alteridade radical em que ele se constitui -, por via da segunda, uma alegoria de tudo o que se entranhou no contato do primeiro com a vida extensiva. Isso implica no forjamento de uma relação visceral entre o Sr... e Costa, o que afinal se configura como uma espécie de relação paternal-filial, complemento direto da idéia de uma nova maternidade a que se ligam Kriska e a língua húngara - mas que, naturalmente, nem de longe significa o estabelecimento de uma relação não-problemática, mesmo porque atravessada, no mínimo, pelos conflitos habituais. Quando a namorada empresta "um gorro e um capote cheirando a cânfora" para Costa se proteger do frio, é evidente - além do sentido purificador usualmente atribuído à cânfora - o duplo sentido de repressão e proteção que as roupas e seu ex-proprietário assumem para o protagonista, sem falar nos traços de rivalidade fálica explícitos na comparação entre seus corpos: "Eram resquícios de um homem de cabeça grande e tronco menor que o meu; o grosso capote de lã repuxava minhas axilas, me impedindo de fechar os braços" ${ }^{11}$ (BP, 70). Rivalidade que culmina no confronto do encontro dos escritores anônimos: quando o reconheceu, narra Costa, o Sr... "me olhou de cima para baixo, apesar de ser bem menor que eu" (BP, 144); e se é ao escritor brasileiro que cabe a vitória nessa disputa em torno da língua materna do outro, é com uma aflição e convulsões que parecem

11. Ao mesmo tempo, são evidentes os traços infantis na construção da imagem do Sr... por Costa, o que se torna mais significativo pelo fato de também ele, de uma certa forma, ser gestado no interior de Kriska - dados que, afinal, ampliam a "agonística" dessas relações. 
revelar algo como um delito incestuoso - em todo caso atestando o grau de entranhamento atingido por aquela relação - que o próprio Costa a assimila: "Entrei no quarto com ânsias, fui à privada, enfiei o dedo na garganta, mas eu não jantara, não tinha o que vomitar" (BP, 146).

Assim, é sob a forma dupla e paradoxal do estranhamento e do entranhamento radicais que o Sr... se configura para o narrador-protagonista. É essa duplicidade que o investe da autoridade enunciativa necessária para engendrar um universo que constitua tanto a subsunção quanto a subtração dos conflitos configurados na diegese narrativa: absortos no fluxo de Costa pelas vagas de palavras e alteridades que irrompem de todos os lados, só a custo percebemos a rede que, antes de alçá-lo ainda convulso, se entretece lentamente com suas próprias entranhas. Não é preciso cogitar se, afinal de contas, em algum momento o próprio Costa deixa de ser o artífice dessa trama para constatar sua afinidade profunda - embora a depure de suas pretensões quase absolutistas - com a mesma malandragem em que se fundava a relação esquiva do protagonista com aquele mundo de luzes e sombras.

Como em Benjamim, há em Budapeste algo de um sonho conduzido por quem sonha: algo de um sonho moldado em água, talvez ainda mais precário que o frustrado sonho de redenção de Benjamim Zambraia, mas que nem por isso deixa de se cristalizar e se eternizar na plenitude de um instante. Mesmo assim, como em Estorvo, as formas desse sonho permanecem quase sempre muito vagas para alcançarem a dimensão dialógica que constitui talvez o maior mérito do segundo romance. Por doloroso que seja, o resgate de Costa/Kósta lhe concede o privilégio de uma segunda infância, pondo-o a salvo das águas turbulentas em que bracejava em sua anti-epopéia radical. Mas no caminho entre a consciência e a abdicação (ainda que astuciosa) da práxis, o reconhecimento e a alegorização (ainda que profunda) do outro, a compreensão e a simulacrização (ainda que poética) da realidade, e ainda que confinando-se à fonte tão clara quanto insondável de Kriska, o malandronarciso permanece à deriva... 
Disponivel em: http://www.letras.ufmg.br/poslit

Abstract: This work aims to analyse the most recent novel of Chico Buarque, Budapeste, dealing with its various games of mirrors in order to reach its major fundamental duplicity: as an "ambidextrous author", which the finest "scriptural cunning", weaved in almost invisible threads in the line spaces of the narrative web, shapes the potence and limits of the statute of the praxis and alterity in its interior.

Key words: Brazilian Literature; Contemporary novel; Chico Buarque.

\section{Referências Bibliográficas}

BUARQUE, Chico. Budapeste. São Paulo: Companhia das Letras, 2003.

COELHO, Marcelo. Estorvo. Folha de São Paulo, São Paulo, 3 ago. 1991. Ilustrada, p. 8.

FERRAZ, Arthur. A travessura de Chico Buarque. Disponível em: <http:// www.noolhar.com/diversaoarte/literatura/320883.html>. Acesso em: 05 jun. 2004.

MOLNÁR, Ferenc. Os meninos da rua Paulo. Rio de Janeiro: Edições de Ouro, s. d.

ÖRKÉNY, István. A exposição das rosas. São Paulo: Ed. 34, 1993.

PAZ, Ravel Giordano. Estações encruzilhadas: o inferno e o sonho, a música e o mundo nos romances de Chico Buarque. 2001. Dissertação (Mestrado) - Unicamp, Campinas.

PIRES, José Cardoso. Uma peregrinação alucinada. Jornal de Letras. Lisboa, p. 1, set. 1991. 